\title{
Experimental research into the effect of some operation factors and rock properties on the rate of penetration
}

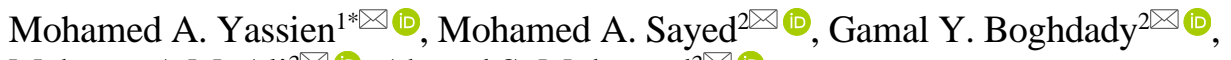 \\ Mahrous A.M. Ali ${ }^{3 \otimes}(\mathbb{0})$, Ahmed S. Mohamed ${ }^{3 \otimes(0)}$ \\ ${ }^{1}$ Al-Azhar University, Cairo, 11651, Egypt \\ ${ }^{2}$ Assiut University, Assiut, 71516, Egypt \\ ${ }^{2}$ Al-Azhar University, Qena, 83215, Egypt \\ *Corresponding author: e-mail mahrous mining@yahoo.co.uk, tel. +20963196008
}

\begin{abstract}
Purpose. The purpose of this research is to investigate the effect of weight on bit (WOB), rotary speed (RPM), and some rock properties on the rate of penetration (ROP).

Methods. Four types of rock were collected from different sites in the south of Egypt (Aswan sandstone, Isawya limestone, Assiut limestone, and Minya marble). These tested samples were drilled by diamond core bit using a fixed laboratory diamond drilling machine under conditions (400 and $1200 \mathrm{rpm}$ ), and loads from 12 to $220 \mathrm{~kg}$. WOB, ROP, torque (T) and specific energy (SE) were continuously observed during the drilling trials. The effect of these factors on ROP were examined. Water is used as a flushing and cooling medium.

Findings. The effect of some operation factors on the penetration rate regarding mineral composition and different rock type was evaluated and the general equation was carried out to predict the suitable operation factor which gives the best penetration Rate.

Originality. The effect of some operation factors on the penetration rate regarding mineral composition and different rock type was evaluated and the general equation was carried out to predict the suitable operation factor which gives the best penetration Rate.

Practical implications. The Results demonstrated that ROP was inversely proportional to compressive strength (CS), tensile strength (TS), and density. It was also found that Aswan sandstone, Isawya limestone, Assiut limestone, and Minya marble have CS 111.94 MPa, 131.22 MPa, 125.0 MPa, and 502.5 MPa respectively. Was established that ROP was directly proportional to porosity. Increasing ROP in case of Aswan sandstone is associated with increase in porosity $-23.158 \%$, and in case of Assiut limestone and Isawya limestone ROP is also associated with an increase in porosity $-19.9 \%$ and $17.93 \%$ respectively. Decreasing ROP in case of Minya marble is associated with decrease in porosity $-2.314 \%$. So, we concluded that marble has lower ROP due to its higher CS, TS, and density and lower porosity than other tested rocks.
\end{abstract}

Keywords: rate of penetration, weight on bit, rotary speed, specific energy

\section{Introduction}

Drilling is one of the most important processes to identify a clear picture of orebody in any mineral exploration. Its mineral content, and the stratigraphic features allow to illustrate both geometry and geological setting, which helps to interpret the layers behavior under surface. Layer thickness and structure influence drilling operations. There are many resistance forces which affect drilling operations, such as shearing action of the bit in rotation and the degree of abrasiveness [1]-[3].

Rate of penetration is considered to be an index for calculating drilling operation cost. The total performance of any drill bit is complex and is affected by several parameters which include:

- bit operating factors;

- formation characteristics;
- bit type and design;

- abrasion index;

- drilling fluid properties;

- flow mechanics;

- hole dimensions;

- machine specifications;

- time, climate and crew and/or operator efficiency.

However, there are the principal parameters that are required in estimating and predicting of ROP and the operating factors of the drill bits and characteristics of the penetrated rock [4].

In order to drill a well, three factors should be recognized simultaneously:

- a certain load should be applied on the bit;

- the bit should be rotated;

- a drilling fluid should be circulated within the well bore. 
The most important variables affecting ROP that have been identified and studied include [5], [6]:

- bit type;

- formation characteristic;

- drilling fluid properties;

- bit operating conditions (bit weight and rotary speed);

- bit tooth wear and bit hydraulics.

Diamond bit drilling is one of the most widely used and preferable drilling techniques because of its higher rate of penetration and core recovery in the hardest rocks, the ability to drill in any direction with less deviation, and the ability to drill with greater precision in scoring and prospecting drilling [7].

Rate of penetration depends on the following geotechnical parameters: compressive strength (CS), tensile strength (TS), porosity, density, hardness, mineral composition and quality of cementation in clastic rock. Decreasing linear relationships were established between ROP, uniaxial compressive strength (UCS), and hardness [8]-[13].

Experimental work was carried out in the department of Mining and Metallurgical Engineering, Engineering Faculty, Assiut University. The locations of the collected rocks samples are shown on the map in Figure 1.

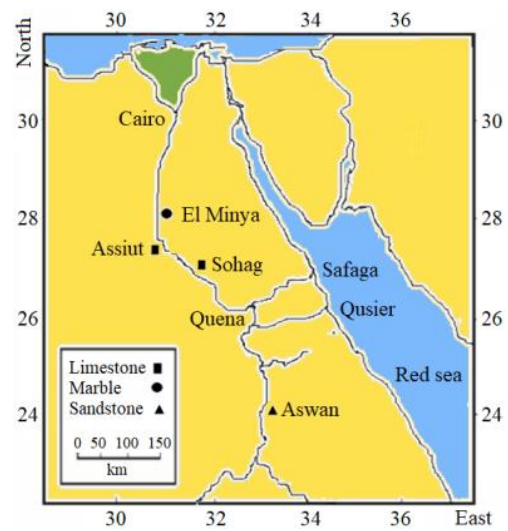

Figure 1. The four locations of the studied rocks

All cores were extracted from two categories of rocks used in this study, namely sedimentary and metamorphic rocks. Sedimentary rocks were represented by samples of sandstone, and limestone. Sandstone was taken from Akaba sandstone quarry in Aswan. Limestone rocks were represented by two types the first from Assiut limestone quarry in Assiut, and the other type from Isawya limestone quarry in Sohag. The metamorphic rocks were represented by the sample of Marble from El sheikh Fadel marble quarry in Minya.

The used bit has outside diameter $5 \mathrm{~cm}$ and inside diameter $4.2 \mathrm{~cm}$. All the drilling series were executed at Rotation speed 1200, 400 RPM. So, the drilling bit has a series of drilling data for the rocks, a certain RPM and the load applied to the bit (Fig. 2).

The aim of this article is to examine the influence of weight on bit, rotary speed, and some rock properties on penetration rate.

\section{Geology of the tested rocks}

The four-rock samples were collected from different governorates in Egypt (Minya, Assiut, Sohag, and Aswan). Several samples of every rock type were tested and examined for petrography. In sub-section, we discuss the final results of thin sections and the description of each rock sample.

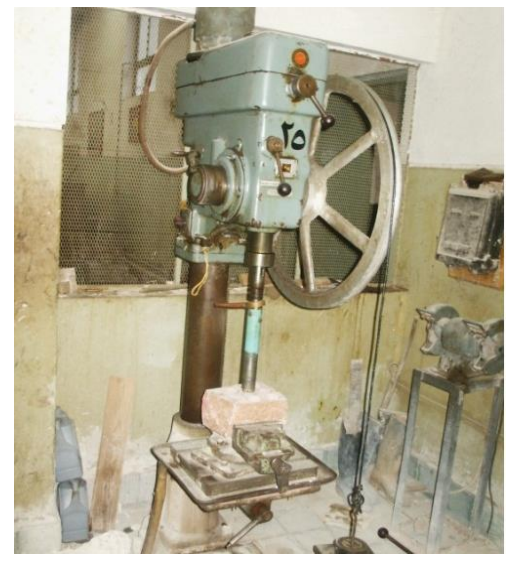

Figure 2. General view of diamond drilling machine

\subsection{Aswan sandstone and Nubian sandstone}

Aswan sandstone, and Nubian sandstone were extracted from the available geological sites of southern Egypt. Nubia Sandstone located over a kilometer deep in the Nubian strata deposited in south western Egypt is controlled primarily by marine transgressions and regressions with alluvial plain sand with interbedded channel and soil zone deposits interleaved with marine clay and silt. This cycle comprises the typical Nubia sandstone and represents continuously changing environments from fluvial and deltaic deposition.

1. Petrography description.

Occurrence - sedimentary.

Hand specimen - brownish to reddish in color.

2. Microscope description.

Texture - granular.

Grain size - medium.

3. Mineralogy.

Essential component - quartz and biotite.

Accessory - plagioclase containing patches of iron oxides.

Figure 3 illustrate sample core preparation and Figure 4 thin section under polarizing and depolarizing microscope.

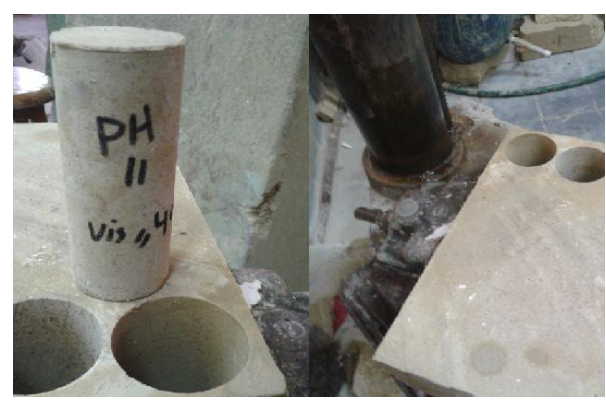

Figure 3. Sample core preparation from Isawya limestone

(a)

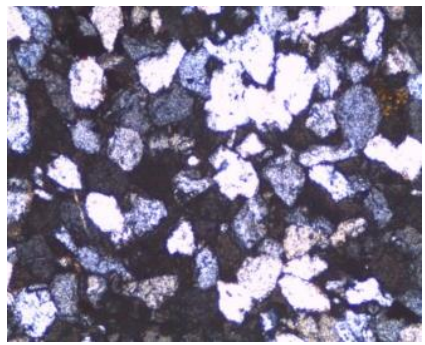

Figure 4. A photomicrograph of the Aswan sandstone: (a) polarizing microscope; (b) depolarizing microscope 


\subsection{Isawya limestone}

Isawya limestone containing different rock types is located in the area east of Sohag, between latitude (26 $\left.333^{\prime} 57^{\prime \prime}\right)$, and longitude (31 $\left.{ }^{\circ} 49^{\prime} 14^{\prime \prime}\right)$, covering about $400 \mathrm{~km}^{2}$. The area under investigation was covered by limestone, sand, silt, clays, conglomerate and red lime-stone breccias. The area between Sohag and Nag Hamadi was investigated geomorphologically and classified in relation to the drainage pattern and drainage types, where the main wades in the area were determined. Carbonate rocks are mineralogically composed mainly of calcite $\left(\mathrm{CaCO}_{3}\right)$ with variable amounts of accessory minerals. A similar proportion is composed predominately of dolomite $\left(\mathrm{CaMg}\left(\mathrm{CO}_{3}\right)_{2}\right)$ which alters considerably in geotechnical properties.

1. Petrography description.

Occurrence - sedimentary.

Hand specimen - white brownish in color.

2. Microscope description.

Texture - lithoclastes.

Grain size - coarse to medium.

3. Mineralogy.

Composed mainly of coarse to medium grain size of lime-stone (lithoclastes, echinoderm frag, nummulites, bryozoa, green algae and fragments of unknown origin), euhedral from calcite and low interference color, fragments of anhedral crystal from quartz and fine disseminated anhedral iron oxide, fossils, calcite, large pores.

Figure 5 illustrates sample core preparation and Figure 6 thin section under polarizing and depolarizing microscope.

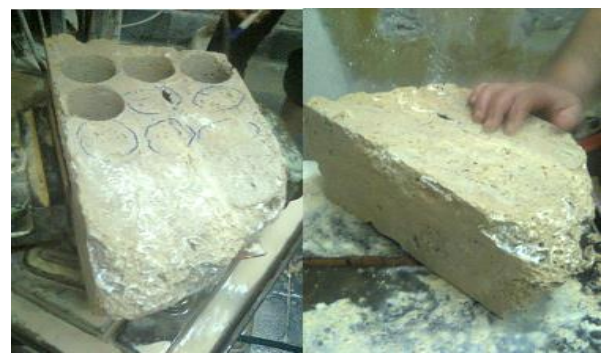

Figure 5. Sample core preparation from Isawya limestone

(a)

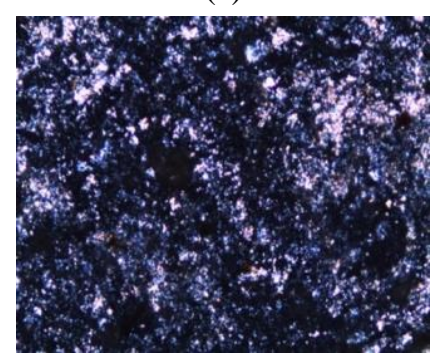

Figure 6. A photomicrograph of the Isawya limestone: (a)polarizing microscope; (b) depolarizing microscope

\subsection{Assiut limestone}

The Assiut limestone that lies to the west of Assuit city is used in cement industry. Its geological formation is related to paleogeographic and structural domain of the Arabian Nubian shelf. Wadi el Assiuty Eocene Plateau bounding the Nile valley near Assiut is composed of limestone (Drunka formation) which is quarried for cement industry.

1. Petrography description.

Occurrence - sedimentary.

Hand specimen - white-grey in color.

2. Microscope description.

Texture - bioclasts.

Grain size - very fine.

3. Mineralogy.

Essential component - calcite.

Accessory - quartz and iron oxides.

Limestone components are from nummulites, green algae, and miliolidae foraminifera with some bioclasts of unknown origin. This rock contains some types of fossils euhedral colors from calcite and low interference color fragment of anhedral crystal from quartz and fine disseminated anhedral iron oxide.

Figure 7 illustrates sample core preparation and Figure 8 thin section under polarizing and depolarizing microscope.

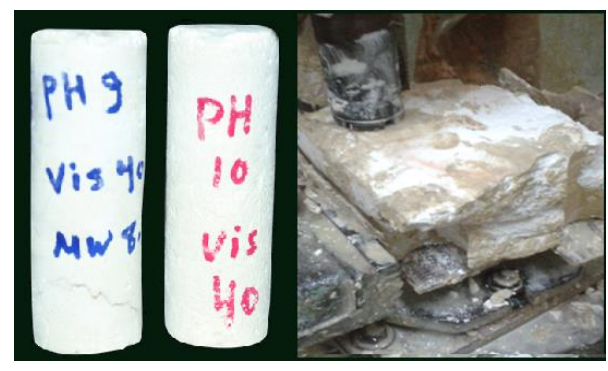

Figure 7. Sample core preparation from Assuit limestone

(a)

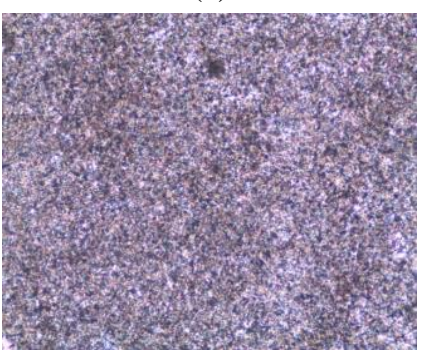

Figure 8. A photomicrograph of the Assuit limestone: (a) polarizing microscope; (b) depolarizing microscope

\subsection{Minya marble}

Minya marble samples were collected from El sheikh Fadel Minya marble quarry. With coordinates: latitude $\left(28^{\circ} 20^{\prime} 49^{\prime \prime}\right)$, longitude ( $\left.31^{\circ} 48^{\prime} 18^{\prime \prime}\right)$ and elevation $43 \mathrm{~m}$. Minya marble is a crystalline, compact variety of metamorphosed limestone, consisting primarily of calcite $\left(\mathrm{CaCO}_{3}\right)$, dolomite $\left(\mathrm{CaMg}\left(\mathrm{CO}_{3}\right)_{2}\right)$ or a combination of both minerals.

Pure calcite is white, but mineral impurities add color in variegated patterns. In terms of geological definition, it is a metamorphosed limestone produced by recrystallization under condition of thermal regional metamorphism. In commercial parlance almost, any rocks consisting of calcium and/or magnesium carbonate which can take polish easily especially unmetamorphosed limestone are termed as marble.

1. Petrography description.

Occurrence-metamorphic.

Hand specimen - white brownish in color.

2. Microscope description.

Texture - mosaic (horn felsic).

Grain size - very fine.

3. Mineralogy.

Essential component - calcite.

Accessory - quartz and iron oxides. 
Both limestone and sand in thin layer and also silt bioclast of uncertain origin and rare-quartz silt with very thin layer from iron oxides. This marble consists of coarse to medium size calcite particles, coarse fossils $<2 \mathrm{~mm}$ rod stone, non-porous, high chemical compaction, high hardness, highly cemented.

Figure 9 illustrates sample core preparation and Figure 10 thin section under polarizing and depolarizing microscope.

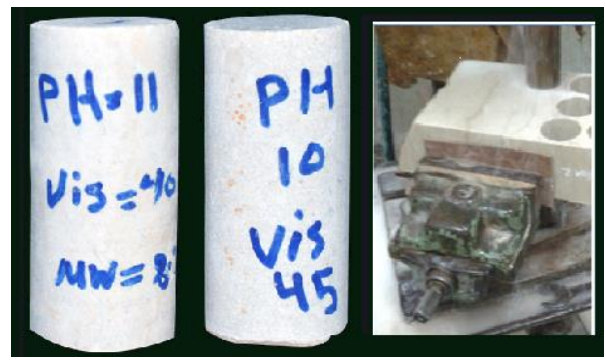

Figure 9. Sample core preparation from Minya marble (a)

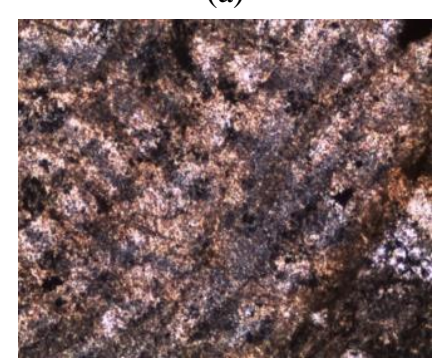

(b)

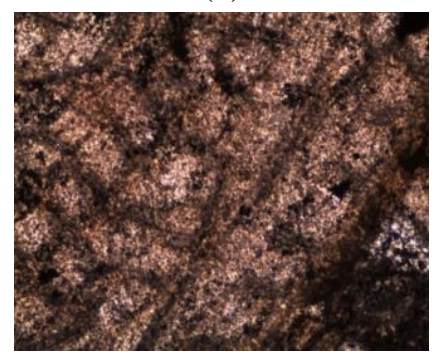

Figure 10. A photomicrograph of the Minya marble: (a) polarizing microscope; (b) depolarizing microscope

\subsection{Properties of the tested rocks}

In this study physical (density, porosity) and mechanical (strength, TS and friction coefficient) properties are examined, and shown in Table 1, which included standard deviation.

\section{Experimental work}

Experiments were performed on sandstone, limestone, and marble samples from four sites of different location (Fig. 1). In the present work, rock samples were extracted by a drilling machine from each kind of samples. The used coring bit has a thin walled impregnated diamond type with the inner diameter $4.2 \mathrm{~cm}$ and the outer one $5 \mathrm{~cm}$. The drilling machine is a fixed laboratory type [14].

The conditions and data of drilling results and samples related to the test were logged. Actual speed, weight, drilling time, and borehole length were monitored and measured. These results were used to determine both the ROP, and the average ROP under the applied load. Trials were performed for a different weight on bit. The weight on bit depends on the rock type and the weight which is effective in getting the higher rate of penetration. All drilling trials were performed at 1200 and $400 \mathrm{rpm}$.

The experimental data of the operating factors are presented in Table 2 and 3. Machine speed (RPM) value taken in the unloaded state. However, the speed decreased over a small range with increasing torque.

\section{Results and discussion}

The effect of both weights on bit (WOB), rotary speed (RPM), on ROP and SE were discussed.

\subsection{Effect of WOB and RPM on ROP}

The effect of WOB and RPM on ROP for all tested rocks is given in Tables 2 and 3 .

\subsection{Relationships between WOB and ROP}

Relationships between WOB and ROP in tested rocks at two rotary speeds 400 and $1200 \mathrm{rpm}$ are given in Figures 11-14.

Table 1. Physical and mechanical properties of the samples

\begin{tabular}{lcccc}
\hline \multicolumn{1}{c}{ Rock type } & Compressive strength, MPa & Tensile strength, MPa & Density, g/cc & \multicolumn{1}{c}{ Porosity, $\%$} \\
\hline Aswan Sandstone & $111.94 \pm 2.52$ & $21.47 \pm 0.712$ & $2.014 \pm 0.0088$ & $23.158 \pm 0.071$ \\
Isawya limestone & $131.22 \pm 4.4$ & $24.05 \pm 0.537$ & $2.13 \pm 0.0068$ & $17.93 \pm 0.15$ \\
Assiut limestone & $125.0 \pm 0.71$ & $15.0 \pm 0.25$ & $2.20 \pm 0.020$ & $19.9 \pm 0.52$ \\
Minya marble & $502.5 \pm 4.11$ & $76.18 \pm 1.83$ & $2.76 \pm 0.00018$ & $2.314 \pm 0.095$ \\
\hline
\end{tabular}

Table 2. Drilling results for operation factors at $1200 \mathrm{rpm}$

\begin{tabular}{|c|c|c|c|c|c|c|c|c|c|c|c|c|}
\hline \multirow{2}{*}{$\begin{array}{l}\text { WOB, } \\
\text { kg }\end{array}$} & \multicolumn{3}{|c|}{ Aswan sandstone } & \multicolumn{3}{|c|}{ Isawya limestone } & \multicolumn{3}{|c|}{ Assuit limestone } & \multicolumn{3}{|c|}{ Minya marble } \\
\hline & $\begin{array}{c}\mathrm{ROP}, \\
\mathrm{cm} / \mathrm{min}\end{array}$ & $\begin{array}{c}\mathrm{T}, \\
\mathrm{N} / \mathrm{m}\end{array}$ & $\begin{array}{c}\mathrm{SE}, \\
\mathrm{MPa}\end{array}$ & $\begin{array}{c}\text { ROP, } \\
\mathrm{cm} / \mathrm{min}\end{array}$ & $\begin{array}{c}\mathrm{T}, \\
\mathrm{N} / \mathrm{m}\end{array}$ & $\begin{array}{c}\mathrm{SE}, \\
\mathrm{MPa}\end{array}$ & $\begin{array}{c}\mathrm{ROP}, \\
\mathrm{cm} / \mathrm{min}\end{array}$ & $\begin{array}{c}\mathrm{T}, \\
\mathrm{N} / \mathrm{m}\end{array}$ & $\begin{array}{c}\mathrm{SE}, \\
\mathrm{MPa}\end{array}$ & $\begin{array}{c}\mathrm{ROP}, \\
\mathrm{cm} / \mathrm{min}\end{array}$ & $\begin{array}{c}\mathrm{T}, \\
\mathrm{N} / \mathrm{m}\end{array}$ & $\begin{array}{c}\mathrm{SE}, \\
\mathrm{MPa}\end{array}$ \\
\hline 12 & 5.33 & 5.04 & 339.6 & - & - & - & 7.66 & 2.75 & 128.9 & - & - & - \\
\hline 18 & 7.42 & 7.55 & 365.5 & - & - & - & - & - & - & - & - & - \\
\hline 24 & 11.25 & 10.07 & 321.5 & 6.84 & 10.49 & 551.9 & 12.36 & 5.52 & 160.4 & - & - & - \\
\hline 30 & 14.64 & 12.59 & 308.9 & - & - & - & - & - & - & 3.81 & 14.3 & 1343.4 \\
\hline 36 & 16.36 & 15.11 & 331.7 & 11.51 & 15.73 & 492.4 & 14.7 & 8.28 & 202.3 & - & - & - \\
\hline 42 & 19.23 & 17.63 & 329.3 & - & - & - & & - & - & - & - & - \\
\hline 48 & 28.80 & 20.14 & 251.2 & 20.42 & 20.98 & 369.9 & 33.72 & 11.05 & 117.7 & - & - & - \\
\hline 54 & 38.00 & 22.66 & 214.2 & - & - & - & - & - & - & - & - & - \\
\hline 60 & 40.57 & 25.19 & 222.9 & 26.90 & 26.22 & 350.9 & 45.16 & 13.81 & 109.8 & 11.36 & 28.5 & 901.09 \\
\hline 66 & 21.74 & 27.70 & 457.7 & - & - & - & - & - & - & - & - & - \\
\hline 72 & - & - & - & 35.31 & 31.46 & 320.9 & 47.12 & 16.57 & 126.3 & - & - & - \\
\hline 84 & - & - & - & 41.18 & 36.71 & 320.9 & 51.13 & 19.33 & 135.7 & - & - & - \\
\hline 90 & - & - & - & - & - & - & - & - & - & 12.42 & 42.7 & 1236.2 \\
\hline 108 & - & - & - & 49.72 & 47.2 & 341.8 & - & - & - & - & - & - \\
\hline 120 & - & - & - & 23.77 & 52.44 & 794.4 & - & - & - & 16.10 & 57.0 & 1271.6 \\
\hline 150 & - & - & - & - & - & - & - & - & - & 10.24 & 71.3 & 2499.1 \\
\hline
\end{tabular}


Table 3. Drilling results for operation factors at 400 rpm

\begin{tabular}{|c|c|c|c|c|c|c|c|c|c|c|c|c|}
\hline \multirow{2}{*}{$\begin{array}{c}\text { WOB, } \\
\mathrm{Kg}\end{array}$} & \multicolumn{3}{|c|}{ Aswan sandstone } & \multicolumn{3}{|c|}{ Isawya limestone } & \multicolumn{3}{|c|}{ Assuit limestone } & \multicolumn{3}{|c|}{ Minya marble } \\
\hline & $\begin{array}{c}\mathrm{ROP}, \\
\mathrm{cm} / \mathrm{min}\end{array}$ & $\begin{array}{c}\mathrm{T}, \\
\mathrm{N} / \mathrm{m} \\
\end{array}$ & $\begin{array}{c}\text { SE, } \\
\text { MPa }\end{array}$ & $\begin{array}{c}\mathrm{ROP}, \\
\mathrm{cm} / \mathrm{min}\end{array}$ & $\begin{array}{c}\mathrm{T}, \\
\mathrm{N} / \mathrm{m} \\
\end{array}$ & $\begin{array}{c}\text { SE, } \\
\mathrm{MPa}\end{array}$ & $\begin{array}{c}\text { ROP, } \\
\mathrm{cm} / \mathrm{min}\end{array}$ & $\begin{array}{c}\mathrm{T}, \\
\mathrm{N} / \mathrm{m}\end{array}$ & $\begin{array}{c}\text { SE, } \\
\text { MPa }\end{array}$ & $\begin{array}{c}\mathrm{ROP}, \\
\mathrm{cm} / \mathrm{min}\end{array}$ & $\mathrm{T}, \mathrm{N} / \mathrm{m}$ & $\begin{array}{c}\text { SE, } \\
\text { MPa }\end{array}$ \\
\hline 12 & 2.96 & 5.04 & 174.7 & - & - & - & 3.15 & 2.75 & 89.6 & - & - & - \\
\hline 24 & 3.06 & 10.08 & 337.7 & 3.03 & 10.49 & 356.1 & 4.09 & 5.52 & 138.5 & - & - & - \\
\hline 30 & - & - & - & - & - & - & - & - & - & 1.29 & 14.26 & 1133.6 \\
\hline 36 & 5.37 & 15.11 & 288.8 & 3.82 & 15.73 & 405.9 & 5.13 & 8.28 & 165.6 & - & - & - \\
\hline 48 & 9.24 & 20.14 & 223.7 & 4.87 & 20.98 & 424.5 & 11.48 & 11.05 & 98.8 & - & - & - \\
\hline 60 & 13.00 & 25.19 & 198.9 & 7.70 & 26.22 & 335.6 & 14.66 & 13.81 & 96.7 & 2.95 & 28.51 & 991.4 \\
\hline 72 & 17.56 & 30.23 & 176.7 & 10.42 & 31.46 & 297.6 & 18.04 & 16.57 & 94.3 & - & - & - \\
\hline 84 & 18.70 & 35.26 & 193.5 & 12.40 & 36.71 & 291.7 & 20.7 & 19.33 & 95.8 & - & - & - \\
\hline 90 & - & - & - & - & - & - & - & - & - & 3.28 & 42.77 & 1337.5 \\
\hline 96 & 8.47 & 40.30 & 488.3 & 14.10 & 41.95 & 293.2 & 16.4 & 22.09 & 138.2 & - & - & - \\
\hline 108 & - & - & - & 16.31 & 47.2 & 285.2 & - & - & - & - & - & - \\
\hline 120 & - & - & - & 17.12 & 52.44 & 301.9 & - & - & - & 4.12 & 57.02 & 1419.7 \\
\hline 132 & - & - & - & 10.75 & 57.69 & 528.8 & - & - & - & & & \\
\hline 150 & - & - & - & - & - & - & - & - & - & 4.74 & 71.28 & 1542.6 \\
\hline 180 & - & - & - & - & - & - & - & - & - & 5.60 & 85.53 & 1566.8 \\
\hline 210 & - & - & - & - & - & - & - & - & - & 3.60 & 99.79 & 2843.4 \\
\hline 12 & 2.96 & 5.04 & 174.7 & - & - & - & 3.15 & 2.75 & 89.6 & - & - & - \\
\hline
\end{tabular}

The trend line for the results shows that increase in WOB produces increase in ROP up to the maximum point. However, it follows from the experimental data in Table 2 and 3 that a further increase in WOB causes constant or little increase or decrease in ROP. The effect of rotational speed on ROP of the bit is clear in the curves and data from Table 2 and 3, i.e. increase in rotary speed produced an increase in ROP.

\subsubsection{Aswan sandstone}

$\mathrm{ROP}$ at the maximum $\mathrm{WOB}=96 \mathrm{~kg}$ was about 2.9 times more than that at the minimum $\mathrm{WOB}=12 \mathrm{~kg}$ at low speed, whereas $\mathrm{ROP}$ at the maximum $\mathrm{WOB}=66 \mathrm{~kg}$ was about 4.1 times more than that at the minimum $\mathrm{WOB}=12 \mathrm{~kg}$ at high speed. ROP increases with increasing rotation speed, ROP at high rotary speed $(1200 \mathrm{rpm})$ is more than ROP at low rotary speed $(400 \mathrm{rpm})$, using a specific load as an example at $\mathrm{WOB}=60 \mathrm{~kg}$, ROP at high rotary speed $(1200 \mathrm{rpm})$ was about 3.12 times ROP at low speed (400 rpm) (Fig. 11).

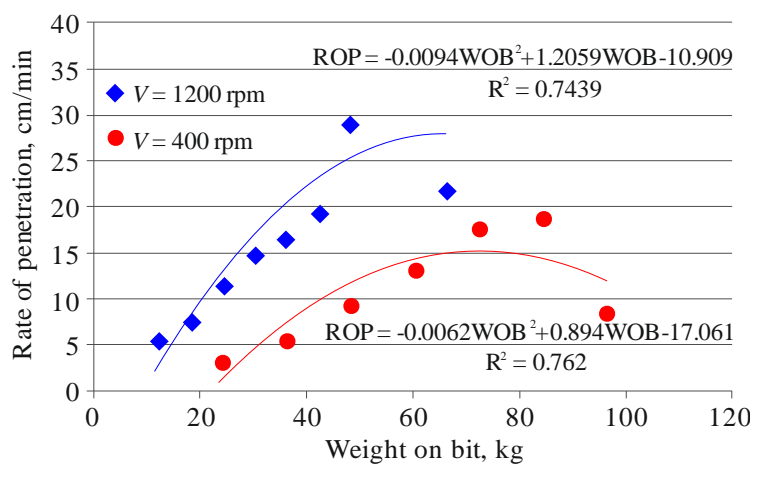

Figure 11. Relationship between WOB and ROP at 400 RPM and 1200 RPM for Aswan sandstone

\subsubsection{Isawya limestone}

ROP increases with the increase in WOB at low and high speed; as shown in Figure 12. ROP at the maximum $\mathrm{WOB}=120 \mathrm{~kg}$ was about 3.48 times more than that at the minimum $\mathrm{WOB}=24 \mathrm{~kg}$ at high speed, whereas ROP at the maximum $\mathrm{WOB}=132 \mathrm{~kg}$ was about 3.55 times more than that at the minimum $\mathrm{WOB}=24 \mathrm{~kg}$ at low speed. ROP increases with an increase in rotation speed, and ROP at high rotary speed $(1200 \mathrm{rpm})$ is more than ROP at low rotary speed $(400 \mathrm{rpm})$, as an example at specified $\mathrm{WOB}=96 \mathrm{~kg}$
ROP at high rotary speed $(1200 \mathrm{rpm})$ was about 2.94 times more than ROP at low speed (400 rpm).

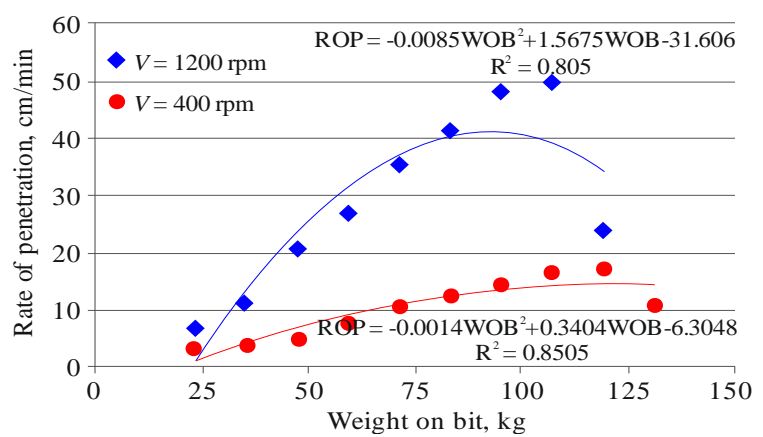

Figure 12. Relationship between WOB and ROP at 400 RPM and 1200 RPM for Isawya limestone

\subsubsection{Assiut limestone}

ROP increases with increase in WOB at low and high speed, as shown in Figure 13. ROP at the maximum $\mathrm{WOB}=96 \mathrm{~kg}$ was about 4.5 times more than at the minimum $\mathrm{WOB}=12 \mathrm{~kg}$ at high speed, whereas ROP at the maximum $\mathrm{WOB}=96 \mathrm{~kg}$ was about 5.2 times more than that at the minimum $\mathrm{WOB}=12 \mathrm{~kg}$ at low speed. ROP increases with growing rotation speed, ROP at high rotary speed $(1200 \mathrm{rpm})$ is more than ROP at low rotary speed (400 rpm), as an example at $\mathrm{WOB}=60 \mathrm{~kg}$ ROP at high rotary speed $(1200 \mathrm{rpm})$ was about 3.1 times more than ROP at low speed (400 rpm).

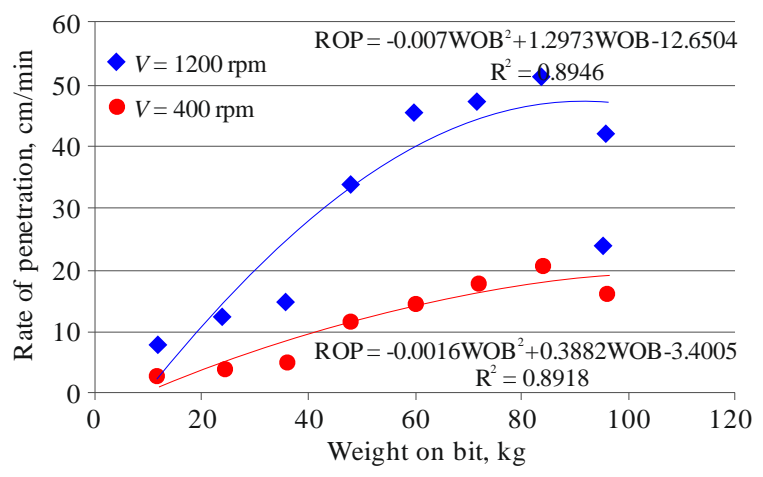

Figure 13. Relationship between WOB and ROP at 400 RPM and 1200 RPM for Assiut limestone 


\subsubsection{Minya marble}

ROP increases with increasing WOB at low and high speed as shown in Figure 14.

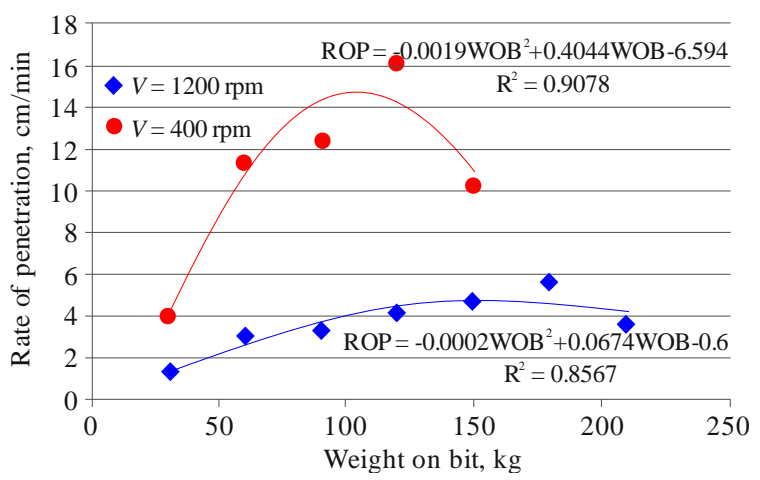

Figure 14. Relationship between WOB and ROP at 1200 RPM and 400 RPM for Minya marble

ROP at the maximum $\mathrm{WOB}=150 \mathrm{~kg}$ was about 2.69 times more than that at the minimum $\mathrm{WOB}=30 \mathrm{~kg}$ at high speed. Whereas ROP at the maximum $\mathrm{WOB}=210 \mathrm{~kg}$ was about 2.79 times more than that at the minimum $\mathrm{WOB}=30 \mathrm{~kg}$ at low speed. ROP increases with increasing rotation speed, ROP at high rotary speed $(1200 \mathrm{rpm})$ is more than ROP at low rotary speed (400 rpm). As an example, at $\mathrm{WOB}=60 \mathrm{~kg}$, ROP at high rotary speed $(1200 \mathrm{rpm})$ was about 3.85 times more than ROP at low speed (400 rpm). For all tested rocks the relationship between WOB and ROP with correlation coefficients is illustrated in all figures.

\subsection{Relations between weight on bit (WOB) and specific energy (SE) in all rocks at low and high speeds}

The SE is defined as the energy required for excavating a volume unit of rock in MPa. It is a useful parameter that may also be taken as an index of the mechanical efficiency of rock mining process. SE is directly linked to the cost used for drilling the hole, so the SE is a clear indication of the drilling performance in the rocks drilled in this study. SE can be defined as input energy to the output ROP. The SE equation can be expressed in terms of drilling parameters in a following equation [15]:

$S E=\frac{2 \pi \cdot N \cdot T}{A \cdot R O P}$,

where:

$S E$ - specific energy, $\mathrm{MPa}$

$N$ - rotary speed, rpm;

$T$ - resistance torque, $\mathrm{Nm}$;

$A$ - area of the bit, $\mathrm{mm}^{2}$.

Specific energy (SE) values were calculated from the above equation for all tests at high and low speeds, and the obtained values were illustrated previously in Table 2 and 3.

For different rocks at $400 \mathrm{rpm}$ and $1200 \mathrm{rpm}$, Figures 1518 introduce the relation between weight on bit (WOB) and SE for all tested rocks, while increase in weight on bit led to increase in SE for all Aswan sandstone rocks at low and high speed. The relations between weight on bit and SE, with correlation coefficients are given in Table 5. In general, at low rotary speed of $400 \mathrm{rpm}$, the increase in ROP leads to increase in SE in most of the tested rocks.

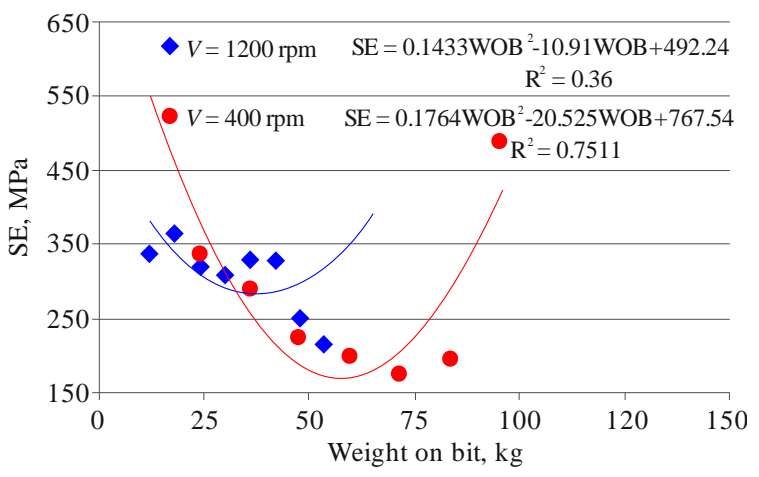

Figure 15. Relationship between WOB and SE at 1200 RPM and 400 RPM for Aswan sandstone

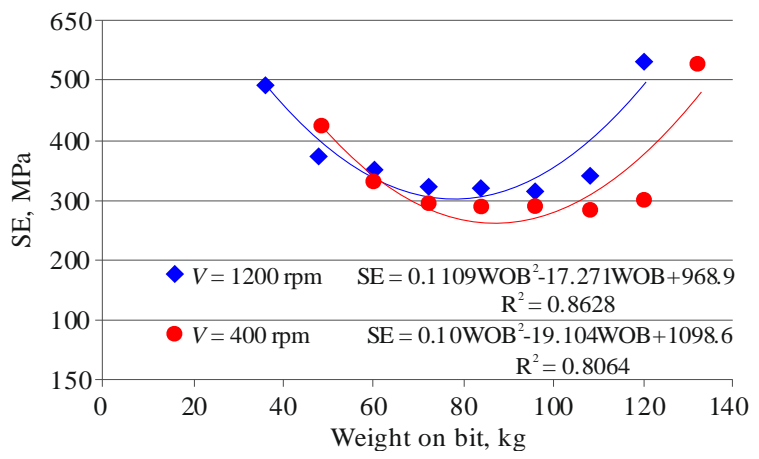

Figure 16. Relationship between WOB and SE at 1200 RPM and 400 RPM for Isawya limestone

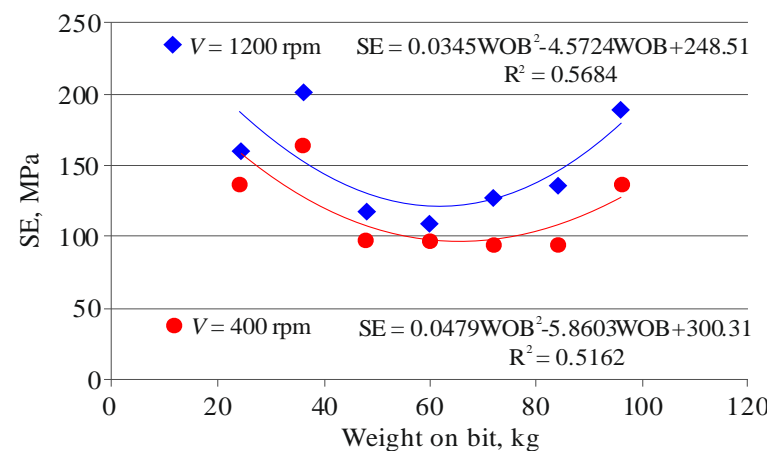

Figure 17. Relationship between WOB and SE at 1200 RPM and 400 RPM for Assiut Limestone

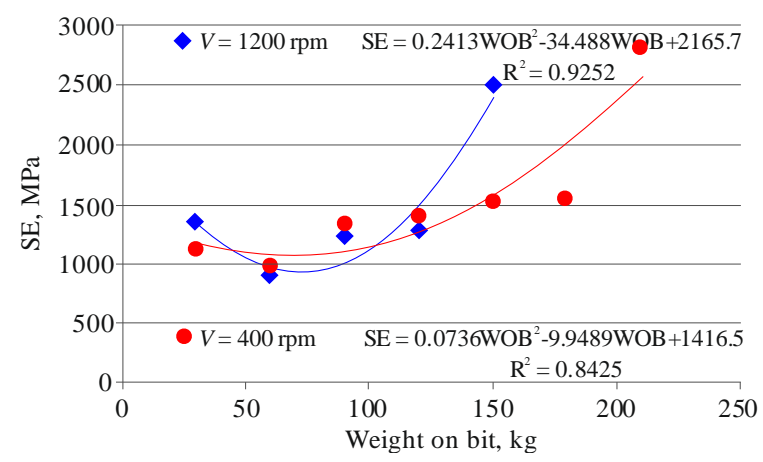

Figure 18. Relationship between WOB and SE at 1200 RPM and 400 RPM for Minya marble

Whereas at high rotary speed of $1200 \mathrm{rpm}$ the increase in ROP leads to decrease in SE in most of the tested rocks. Then, high rotary speed is more suitable than low speed in drilling these kinds of rocks. In the tested rocks, the relationship between SE and WOB with correlation coefficient is shown in all figures. 


\subsection{Effect of rock type on the rate of penetration and specific energy}

At constant $\mathrm{WOB}=60$ and $\mathrm{RPM}=1200$ the ROP value of the bit in Assiut and Isawya limestone and Aswan sandstone has a range from 2.5 to 5 times more than that of Minya marble. This is because the Marble has higher density and compressive strength than any other rock and lower value of porosity. On the other hand, the specific Energy (SE) in case of Minya marble is 9 times, 3 times, and 4 times more than that for Assiut limestone, Isawya limestone and Aswan sandstone respectively.

\section{Conclusions}

From the laboratory research carried out on the selected rocks it can be summarized that:

Rate of penetration at high speed is more than that at low speed under a specific load. At WOB of $60 \mathrm{~kg}$ as an ex-ample ROP at high speed were about 3.12, 3.49, 3.08 and 3.85 times more than ROPs at low speed in rocks Aswan sandstone, Isawya limestone, Assiut limestone and Minya marble respectively.

At $\mathrm{WOB}=60 \mathrm{Kg}$, ROP will be $1200 \mathrm{rpm}$ in Assiut limestone, which is about $1.68,1.11$, and 3.98 times more than that of the Isawya limestone, Aswan sandstone and Minya marble respectively.

At low WOB, SE increases for the four types of rock, and increasing WOB is associated with decrease in SE to a certain limit, then decreasing WOB results in increasing SE.

WOB that gives the lower value of SE is the optimum WOB. From the results, it was found that the suitable value of WOB is $60 \mathrm{~kg}$ for drilling in Aswan sandstone, $96 \mathrm{~kg}$ for drilling in Isawya limestone, $84 \mathrm{~kg}$ for drilling in Assiut limestone and $120 \mathrm{~kg}$ for drilling in Minya marble at 1200RPM. Optimum WOB at $400 \mathrm{rpm}$ is $84 \mathrm{~kg}$ for drilling in Aswan sandstone and Assiut limestone, $120 \mathrm{~kg}$ WOB for drilling in Isawya limestone, and $180 \mathrm{~kg}$ for drilling in Minya marble at 400 RPM.

At low and high rotary speed increasing WOB causes an increase in ROP. In Aswan Sandstone rock at a maximum $\mathrm{WOB}=96 \mathrm{~kg}$, ROP was about 2.8 times more than that of at the minimum $\mathrm{WOB}=12 \mathrm{~kg}$. Rate of Penetration increases in rocks (Isawya limestone, Assiut limestone) and (Minya marble) at $\mathrm{WOB}=132,96$, and $210 \mathrm{~kg}$ was about 3.55 , 5.21 , and 2.79 times that at 24,12 , and $30 \mathrm{~kg}$ respectively to the low speed.

It is found that Isawya limestone needs 3.20 times more SE than Assiut limestone and 1.57 times more SE than Aswan sandstone, whereas Minya marble needed 8.21 times more SE than Assiut limestone and 2.57 times more than Isawya limestone and 4.04 times more than Aswan sandstone at $60 \mathrm{~kg}$ and high speed to complete this operation.

Specific Energy is inversely proportional to ROP in all tested rocks. The machine consumed 9.37 times more energy for drilling Minya marble than for drilling Assiut limestone, and the energy consumption was 5.70 and 4.04 times more than that of Aswan sandstone and Isawya limestone respectively.

There was a correlation between ROP and some rock properties. We found that ROP was inversely proportional to compressive strength (CS), tensile strength (TS), and density.
Accordingly, we found that Aswan sandstone, Isawya limestone, Assiut limestone, and Minya marble have the following $\mathrm{CS}=111.94,131.22,125$, and $502.5 \mathrm{MPa}$ respectively. Whereas we found that ROP was directly proportional to porosity. Increasing ROP in case of Aswan sandstone is associated with increase in porosity $(23.158 \%)$, and in case of Assiut limestone and Isawya limestone is associated with increase in porosity (19.9 and 17.93\%) respectively vice versa. Decreasing of ROP in case of Minya marble is associated with decrease in porosity $(2.314 \%)$.

\section{Acknowledgements}

Our sincere gratitude for Mining and Metallurgical Engineering Dept. Faculty of Engineering, Assiut, Egypt for invaluable assistance to upgrade and guidance to completed this article.

\section{References}

[1] Thuro, K. (1997). Drillability prediction: geological influences in hard rock drill and blast tunnelling. Geologische Rundschau, 86(2), 426438. https://doi.org/10.1007/s005310050151

[2] Mahrous, M.A. Ali, Abdellah, W., \& A.K. Abd El Aal. (2016). Drillability prediction using regression analysis for some Egyptian rocks. International Journal of Research in Engineering and Technology, 05(10), 138-149. https://doi.org/10.15623/ijret.2016.0510023

[3] Mahrous, A.M. Ali, \& Yang, H.S. (2012). Determination of drillability of some different concrete layers and their association with concrete properties. In Al-Azhar Engineering Twelfth International Conference (pp. 23-27). Cairo, Egypt.

[4] El-Biblawi, M.M., Sayed, M.A., Mostafa, T.M., \& El-Rawy, W.R. (2007). Some drilling parameters as a tool to predict different categories of rocks. Journal of Engineering Sciences, 35(4), 995-1008.

[5] Gamal, Y. Boghdady. (2010). Mechanical and geological influences on drilling limestone rock at low rotary speed. Journal of Engineering Sciences, 38(1), 259-270.

[6] Mohamed, A.Y., Mohamed, A. Sayed, \& Gamal, Y. Boghdady, Mahrous, A.M. Ali, \& Ahmed, S. Mohamed. (2018). Investigation the effect of some drilling fluid properties on rock drilling rate. International Journal of Scientific \& Engineering Research, 9(2), 1-6.

[7] AL-Mahasneh, M. (2017). Optimization drilling parameters performance during drilling in gas wells. International Journal of Oil, Gas and Coal Engineering, 5(2), 19-26. https://doi.org/10.11648/j.ogce.20170502.12

[8] Bilgin, N., \& Kahraman, S. (2003). Drillability prediction in rotary blast hole drilling. In International Mining Congress and Exhibition To Turkey-Imcet.

[9] Sayed, M., Boghdady, G., \& Abdellah, W. (2018). Determination of the suitable drilling operating parameters in different geological formations El-Sharara Oil Field (South-Western Libya). Mining of Mineral Deposits, 12(3), 1-8. https://doi.org/10.15407/mining12.03.001

[10] Olgay, Y., \& Eren, S. (2011). The effect of mechanical rock properties and brittleness on drillability. Scientific Research and Essays, 6(5), 1077-1088.

[11] Yarali, O., \& Kahraman, S. (2011). The drillability assessment of rocks using the different brittleness values. Tunnelling and Underground Space Technology, 26(2), 406-414. https://doi.org/10.1016/j.tust.2010.11.013

[12] Altindag, R. (2003). Estimation of penetration rate in percussive drilling by means of coarseness index and mean particle size. Rock Me-

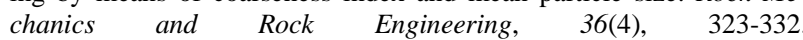
https://doi.org/10.1007/s00603-003-0002-3

[13] Babatunde, A., Zacheus, O.O., \& Jide, M.A. (2010). Drillability and strength characteristics of selected rocks in Nigeria. AU Journal of Technology, 14(1), 56-60.

[14] Kivade, S.B., Murthy, C.S.N., \& Vardhan, H. (2015). Experimental investigations on penetration rate of percussive drill. Procedia Earth and Planetary Science, (11), 89-99. https://doi.org/10.1016/j.proeps.2015.06.012

[15] Imbaby, S.S. (1980). Study of some factors affecting the drillability of rocks. M.Sc. Thesis. Assiut University: Faculty of Engineering. 


\section{Експериментальне дослідження впливу деяких експлуатаційних параметрів та властивостей гірських порід на швидкість буріння}

\section{М. Ясен, М. Саєд, Г. Богдаді, М. Алі, А. Мохамед}

Мета. Вивчення впливу комплексу основних експлуатаційних параметрів і ряду фізико-механічних властивостей порід на швидкість буріння в умовах різних родовищ Південного Єгипту.

Методика. Були відібрані 4 типи порід з різних районів на півдні Єгипту (Асуанської піщаник, вапняк Ісав, Ассіутскій вапняк і мармур Міньї). Експериментальні зразки отримано на стаціонарній лабораторній буровій установці з алмазним долотом при швидкостях обертання 400 і 1200 об/хв та при навантаженнях від 12 до 220 кг. Під час експериментів постійно вимірювалися навантаження на долото, частота обертання, крутний момент на долоті й питома енергія, а також досліджувався вплив цих факторів на швидкість буріння. Як розчин для промивання і охолоджуючий агент використовувалася вода.

Результати. Встановлено залежності швидкості буріння від навантаження на долото, питомої енергії та частоти обертання і питомої енергії. Виявлено, що для всіх чотирьох типів породи швидкість буріння збільшується з ростом навантаження на долото, в той час як питома енергія зменшується з ростом швидкості буріння. Розроблено ефективний спосіб прогнозування продуктивності бурової установки. Встановлено, що швидкість буріння обернено пропорційна міцності на стиск, міцності на розтягнення й щільності, а також змінюється прямо пропорційно пористості. Визначено, що менша швидкість буріння мармуру пов'язана 3 великими значеннями міцності на стиск, розтяг і щільність, а також з меншою пористістю у порівнянні з іншими досліджуваними породами.

Наукова новизна. Встановлено нові закономірності взаємозв'язку експлуатаційних параметрів буріння з урахуванням різного типу породи (пісковик, вапняк, мармур) та її мінерального складу, а також обгрунтовано головну умову експлуатаційного фактору, який забезпечує оптимальну швидкість буріння.

Практична значимість. Отримані результати дозволяють вибирати оптимальні параметри і режими буріння в процесі розвідки умов залягання родовищ Південного Єгипту, їх мінерального вмісту та стратиграфічних особливостей. Результати будуть корисними для проектних організацій, наукових інститутів з геології й розвідки, а також гірничих підприємств.

Ключові слова: швидкість буріння, навантаження на бурове долото, частота обертання, питома енергія, гірська порода, міцність, щиільність, пористість

\section{Экспериментальное исследование влияния некоторых эксплуатационных параметров и свойств горных пород на скорость бурения}

\section{М. Ясен, М. Саед, Г. Богдади, М. Али, А. Мохамед}

Цель. Изучение влияния комплекса основных эксплуатационных параметров и ряда физико-механических свойств пород на скорость бурения в условиях пород различных месторождений Южного Египта.

Методика. Были отобраны 4 типа пород из различных районов на юге Египта (Асуанский песчаник, известняк Исавии, Ассиутский известняк и мрамор Миньи). Экспериментальные образцы получены на стационарной лабораторной буровой установке с алмазным долотом при скоростях вращения 400 и 1200 об/мин и при нагрузках от 12 до 220 кг. Во время экспериментов постоянно измерялись нагрузки на долото, частота вращения, крутящий момент на долоте и удельная энергия, а также и исследовалось влияние этих факторов на скорость бурения. В качестве промывочного раствора и охлаждающего агента использовалась вода.

Результаты. Установлены зависимости скорости бурения от нагрузки на долото, удельной энергии и частоты вращения и удельной энергии. Выявлено, что для всех четырех типов породы скорость бурения увеличивается с ростом нагрузки на долото, в то время как удельная энергия уменьшается с ростом скорости бурения. Разработан эффективный способ прогнозирования производительности буровой установки. Установлено, что скорость бурения обратно пропорциональна прочности на сжатие, прочности на растяжение и плотности, а также изменяется прямо пропорционально пористости. Определено, что меньшая скорости бурения мрамора связана с большими значениями прочности на сжатие, растяжение и плотности, а также с меньшей пористостью по сравнению с другими исследуемыми породами.

Научная новизна. Получены новые закономерности взаимосвязи эксплуатационных параметров бурения с учетом различного типа породы (песчаник, известняк, мрамор) и ее минерального состава, а также обосновано главное условие эксплуатационного фактора, который обеспечивает оптимальную скорость бурения.

Практическая значимость. Полученные результаты позволяют выбирать оптимальные параметры и режимы бурения в процессе разведки условий залегания месторождений Южного Египта, их минерального содержание и стратиграфических особенностей. Результаты будут полезными для проектных организаций, научных институтов по геологии и разведке, а также горных предприятий.

Ключевые слова: скорость бурения, нагрузка на буровое долото, частота вращения, удельная энергия, горная порода, прочность, плотность, пористость

\section{Article info}

Received: 1 February 2019

Accepted: 22 January 2020

Available online: 3 February 2020 